\title{
A COMPARATIVE STUDY OF CRITICAL SUCCESS CRITERIA ON SUSTAINABLE HOUSING; A CASE OF - LOW INCOME HOUSING, SRI LANKA.
}

\author{
RAMANAYAKE R M D T ${ }^{1} \&$ CHETHIKA ABEYNAYAKE ${ }^{2}$ \\ 1,2Department of Town and Country Planning, University of Moratuwa, Sri Lanka \\ 1tharuramanayake1996@gmail.com, ${ }^{2}$ chethika.abenayake@gmail.com
}

\begin{abstract}
Sustainable housing is a popular topic with regard to the SDG, sustainable communities and Sustainable cities. Although different researches have come up with regard to different CSC of specific contexts there are very limited studies on CSC on Sustainable low-income housing. This research aims to compare the CSC on Sustainable lowincome Housing in designing stage in Sri Lankan Context. 18 CSC were derived from comprehensive literature review and re-examined through the 27 professionals and ranked from community on three locations. Relative Importance Index- RII, Min Max Normalization and Gap analyses were employed in the ranking process of Critical Success Criteria. The highest importance has been ranked with Efficiency use of water and energy, Users Satisfaction and Quality of Housing while least importance is ranked with Maintainability, Public Consultation and community participation and cater for Disables and by Literature, Experts and Community respectively. Anyway, Public Consultation and Community Participation, newly derived CSC which is highly ranked among community is to be concentrated among the professionals for the attention and applications in practices. The findings of the research would support to the designers, architectures, planners specialized in this field to ensure the successful delivery of sustainable housing.
\end{abstract}

Keywords: Critical Success Criteria, Sustainable housing, Low income, Design stage

\section{Introduction}

Housing is a basic need of human life. According to "1948 United Nations Universal Declaration of Human Rights", it declared "Everyone has the right to a standard of living adequate for the health and well-being of himself and of his family including food, clothing, housing and medical care and necessary social services...". According to the 11th SDG, it is mentioned to "Make cities and human settlements inclusive, safe, resilient and sustainable" in which Sustainable housing can merely cover many SDGs in the Agenda. "Sustainability housing could be defined as housing practices, which strive for integral quality (including economic, social, and environmental performance) in a broad way (John et, al 2005)". Thus, "sustainable housing must aim at economic, social and environmental sustainability from planning to implementation phase and at the same time result in housing that is affordable, accessible and environmentally less damaging (Choguill, 1994)".

Success of a project is determined with a blend of different factors. Project success criteria can pave the way for the success of the project minimizing the downfalls and failures. In 1960s, the early days of project management, "Success was measured entirely in technical terms. Either the deliverable product worked or it didn't. (O'Brochta, 2002)." In 1990s the project success depends on triple objectives of "Time, Cost and Quality". Many researchers propounded that as project success is a complex task it can't be accessed only through these three criteria. "CSC are the set of principles or standards through which judgement can be made whereas critical success factors (CSF) are the set of circumstances, fact or influences which affect/contribute to the results or CSC (Lim et, al 1999).

Rapid urbanization and recent growing factors seek high demand of housing in urban areas making sustainable housing an important aspect. Once it is a project while once it is a process. As planners are 
incooperated with the planning and design stages, which are considered as prominent stages the study of CSC is an important aspect. Sustainable housing concepts are differing from developed into developing countries. Affordable sustainable housing is a challenge in developing countries due to economic barriers.

"CSC serve as measures to guide developers and governments to enhance efficient allocation of the limited resources to meeting the residential needs of the household (Chua, et al 1999)" As the sustainable housing plays a vital role during the housing developments identification of CSC is an important topic. As well as these studies support to fill the gap between the affordability and sustainability housings in Sri Lankan context with regard to other countries. "The developed framework could be used as a model by public housing authorities and real estate developers for measuring success in housing delivery (Adabre, et al 2018)"

In spite of the background, the study relies on two objectives of Identification of CSC of designing Sustainable Low-income housing in Sri Lankan context and comparison of the derived CSC among Local expert opinion, community perception and literature-based knowledge. This exploratory study attempts to make a significant contribution by filling the gap under : First, many contemporary researches have been conducted under different areas but have not on CSC on Sustainable low-income housing in housing designing stage in Sri Lankan context ((Silva et,al 2019,Yalegama et,al 2016)).Second this study erases the Methodological Limitations using community perceptions without limiting to literature reviews and experts' opinions ((Adabre et, al 2018, Mulliner et, al 2011)).

When it comes to research questions one of the main derived questions is What are the CSC of designing sustainable, low-income housing in Sri Lankan context. The other is How to differentiate the CSC of designing sustainable, low-income housing among local expert opinion, community perception and literature-based knowledge. The research focused based on these questions. In order to achieve the objectives of the study, CSC of sustainable low-income housing developments were identified through a systematic literature review and CSC that are related to the design process of the housing were filtered heuristically. Secondly, the filtered CSC were further examined and prioritized based on the perception of professional experts and residential community of selected housing schemes. Thirdly, a comparative analysis was done based on literature rankings with the perceptions of experts and residents with an emphasis on the global perspectives.

Understanding the CSC of SH developments is an important aspect in regard to the Project Management along with the urban development planning. As Sri Lanka follows a sustainable development pathway in the urban development process referring to SDGs, identification of CSC of sustainable housing is a crucial and vital action in the planning and decision-making process. As WB and UN economic classifications of the countries differentiate as developed developing and less developed countries (Nations, 2020) it is needed to identify CSC customized to the economic status of a country. Sri Lankaspecific CSC of sustainable housing has not been done so far, but a plenty of related international studies were available and those were to considered in the literature review.

\section{Research Methodology}

Objective of the study was to identify the CSC on Sustainable low-income housing in design stage in Sri Lanka. During the research process a mixed approach including a quantitative and qualitative methods were utilized. A mixed methods approach to research is one that involves assembling both numeric information on instruments and as text information on interviews or observation. (Mackenzie et, al 2006). According to (Johnson 2019), "mixed methods research (MMR) can address the timeless issue of causeand-effect or causation".

First, CSC of sustainable low-income housing developments were identified through a systematic literature review including generic and specific criteria. CSC that are related to the design process of the housing were filtered heuristically. Secondly, the filtered CSC were further examined and prioritized based on the perception of professional experts and residential community of selected housing schemes. When it comes to the stage of data collection expert survey questionnaire was prepared based on the CSC derived through the extensive literature review. Then snowball technique was used as sample method for expert survey with 27 sample sizes to interview the experts of designing stage on Sustainable low-income housing in Sri Lankan context. Based on CSC derived from expert's opinions and extensive literature review Survey questionnaire was prepared for community perception. Then random sampling technique with 180 sample size was employed on community perception survey on CSC of SH on three locations. Relative Important Index, Min max Normalization techniques were employed in quantitative data analysis process while NVivo 
technique was used in qualitative analysis. Thirdly, a comparative gap analysis was done based on three rankings of literature rankings with Global context, the perceptions of experts in Sri Lankan context and residents of the selected housing schemes to differentiate the importance of rankings.

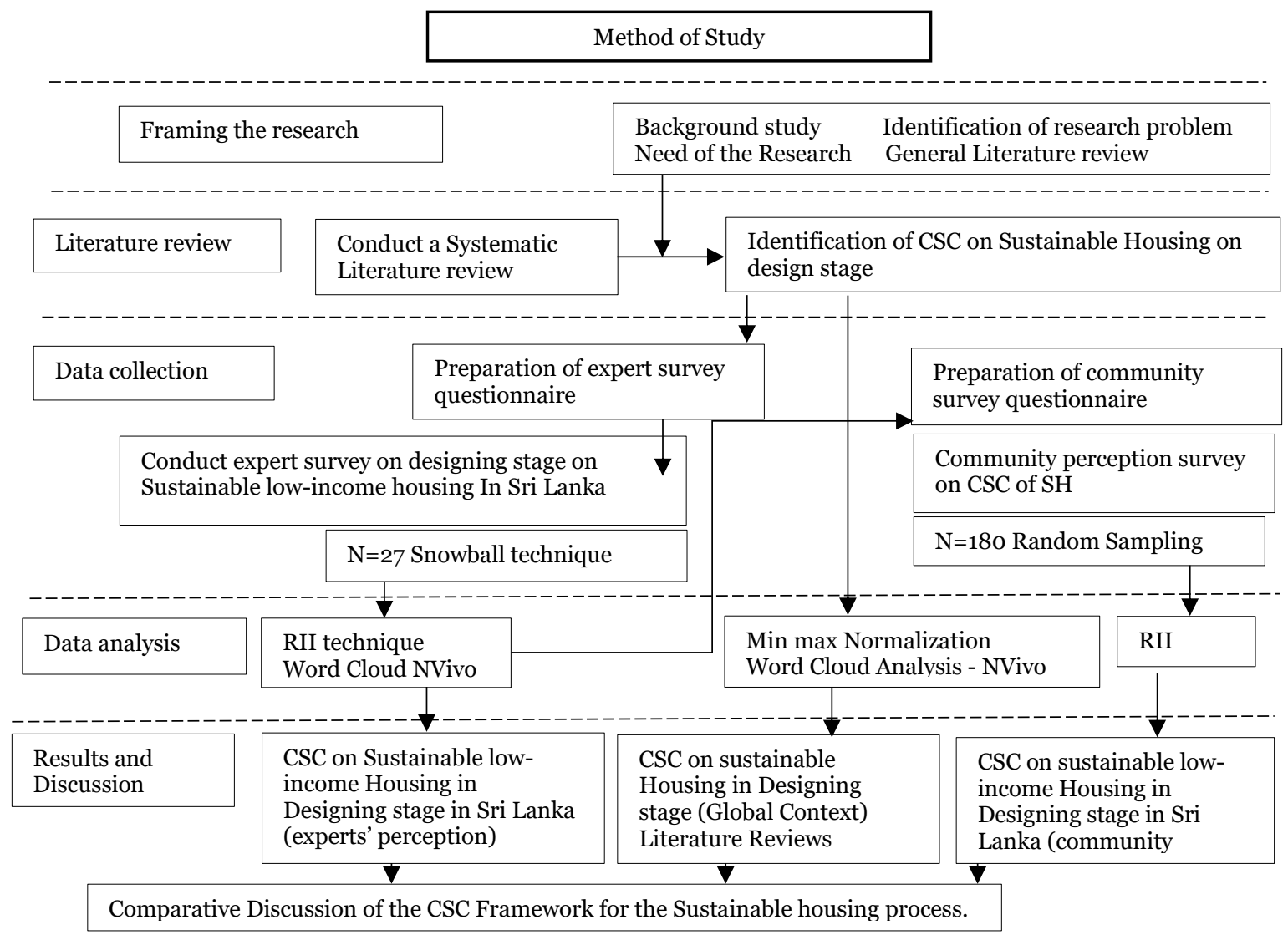

Figure 1: Research Flow

\section{Systematic Review of CSC of Sustainable Housing}

Housing is a basic need of human life. According to Winston (Zinkernagel.R, 2001) "Housing is an essential aspect of life quality and it is also significant for sustainable development". "Housing is where successive generations find shelter to keep healthy, develop, socialize, be educated and prepare for fulfilling adult lives. In this sense, housing speaks to every dimension of personal human development, hopefully generating a double sense of identity and social belonging. If the "emerging futures" of our cities are to become sustainable, then the housing conditions of one billion slum residents must become sustainable, too (UN Habitat, 2016)".

Sustainable housing is a well-rooted concept which was globally emphasized with regard the SDG of sustainable cities and communities. "Sustainable housing refers to the integral quality of economic, social and environmental sustainability of housing practices ((Choguill, 1994); (Chiu, 2003); (John et, al 2005);(UN Habitat, 2012))". Economic sustainability of housing is primarily referred to the affordability (Choguill, 1994); (UN Habitat, 2012)). Social sustainability of housing has been elaborated with the qualities of accessibility (Choguill, 1994), social justice and cultural impacts of housing (UN Habitat, 2012). Environmental sustainability is referred to environmentally fewer damaging practices (Choguill et, al 1994) including energy efficiency and resources, safety and environment health, and recover ability to natural disasters (UN Habitat, 2012). The definition of sustainable housing remains broad. It means not only low-carbon, zero-energy, high performance or green houses, but also covers the characteristics of energy efficiency, resource usage, natural and socio-cultural systems, growth and economic demands and the lifestyle of current generations ((Chiu, 2003); (Cole, 2005); (Yang et, al 2015))

In the developed countries like Australia, New Zealand, the concept of sustainability housing primarily relies on green buildings and energy efficient low carbon concepts ((Choguil,1994); (Thorns, 2004) ;(Iwamura, 2017) ;(Moore et, al 2018)). When the houses are eco efficient, less energy, less carbon 
emissions and less water are consumed supporting the environmental equilibrium. Further, developed countries are focused on the social wellbeing, community developments of sustainable housing ((Thorns, 2004) ;(Iwamura, 2017)). “At the end of the 80's, there arose a tendency of thoughts to recognize the necessity to come up with all these issues of resource, energy, immediate loadings, health \& amenities as a comprehensive environmental issue to support for the creation of a sustainable society in Japan (Iwamura, 2017)".

When consider about sustainable housing concept in developing countries, it blends with the affordability than the green and energy efficiency. According to the findings, it revealed that the number of poor people living in undeserved settlements including slums and shanties in developing countries will be increased to 1.4 billion by 2020. ((Gan, et al 2017); (Desai, 2012)). "The world's urban population is expected to grow from 3.6 billion in 2011 to 6.3 billion in 2050, while $94 \%$ of the increase will occur in developing countries (UN Habitat, 2012)". In order to meet with the needs of the people the governments take actions to provide affordable sustainable houses. Most of the developing countries consider the sustainable housing on affordability concepts. In the developing countries need of a shelter is highly considered without much emphasize on the environmental sustainability concepts ((Duplessis, 2002); (GOI, 2007)). There is a misconception that sustainable housings are highly expensive when regard to conventional housing developments. Nevertheless, sustainable housing to be given at an affordable rate (GOI, 2007). In the developing countries social housing, affordable housing, public housing is used interchangeably to refer the sustainable housing concepts.

Success Criteria is a term evolved from the domain of project management. These criteria can usually be measured that will define the success of the project. SC are measures principles or standards used to judge the success or failure of the projects ((Al-Ageeli et, al 2016); (Srimathi et, al 2017); (Lim et, al 1999)). Other than the project success or failure the SC reflects the project goals. (Kylili A. F., 2016). "In the 1960s, the early days of project management, success was measured entirely in technical terms. Either the deliverable product worked or it didn't (O'Brochta, 2002)". In 1990' s it popped up that project success depends on based on triple objectives of Time, Cost and quality. Many researchers suggest that success can't be assessed only through these three criteria since project success is more complex. The complexity of SC has been further elaborated interpreting housing as process than a project.

Results of the systematic literature review revealed that the sustainable housing developments in the context of developing countries and developed countries have differences in perception. In developed countries, more emphasis is given to energy efficiency and green building whereas in developing countries on elimination of homelessness and the affordability of housing. As Sri Lanka is a developing country, sustainable housing might be blended with the affordability concept.

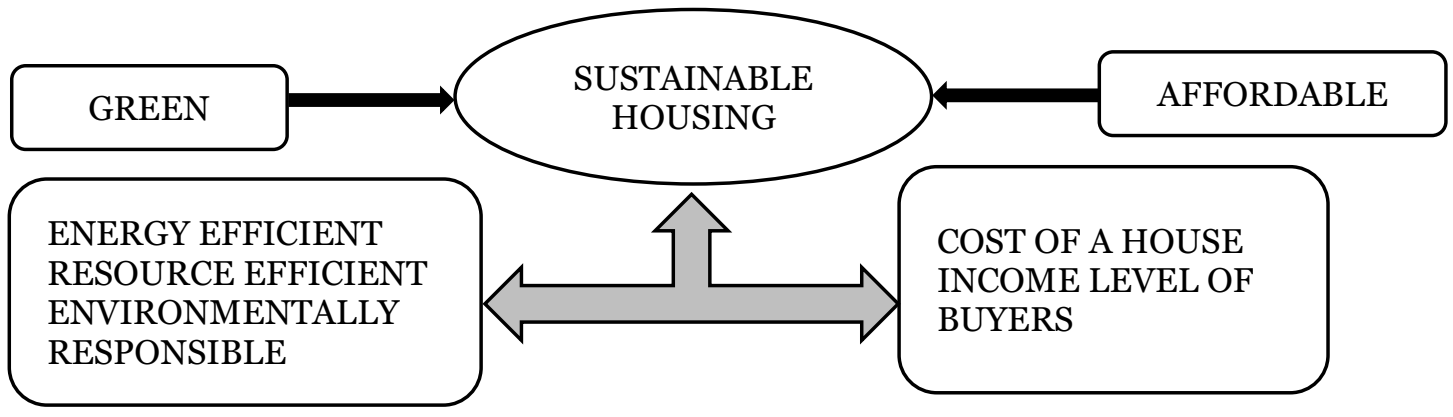

Figure 2: Conclusion on literature reviews Source: Author prepared based on the literature review

\begin{tabular}{|c|c|c|c|c|c|c|c|c|c|c|c|c|}
\hline \multirow[t]{2}{*}{ CODE } & \multirow[t]{2}{*}{ CSC } & \multicolumn{11}{|c|}{ REFERENCES } \\
\hline & & $\mathrm{a}$ & $\mathrm{b}$ & C & $\mathrm{d}$ & $\mathrm{E}$ & $\mathrm{f}$ & $\mathrm{g}$ & $\mathrm{h}$ & i & $\mathrm{j}$ & $\mathrm{k}$ \\
\hline 01 & Cost Performance & $*$ & $*$ & $*$ & $*$ & $*$ & * & * & * & & * & $*$ \\
\hline 02 & Quality of housing & $*$ & $*$ & $*$ & * & $*$ & * & $*$ & * & * & $*$ & $*$ \\
\hline 03 & Schedule performance/ Timely completion & $*$ & $*$ & & * & $*$ & * & $*$ & * & & $*$ & $*$ \\
\hline 04 & Safety / Health Performance & * & * & * & * & $*$ & * & * & * & * & * & * \\
\hline 05 & Environmental performance & $*$ & $*$ & $*$ & * & $*$ & $*$ & $*$ & * & $*$ & & $*$ \\
\hline 06 & Team satisfaction & $*$ & $*$ & & & & $*$ & & * & & & $*$ \\
\hline 07 & User's satisfaction/ End-users Satisfaction & $*$ & * & $*$ & $*$ & $*$ & $*$ & $*$ & * & $*$ & & * \\
\hline 08 & Productivity/efficiency of water, energy use & * & * & $*$ & & & & $*$ & $*$ & $*$ & & $*$ \\
\hline 09 & Functionality & $*$ & * & & & & & $*$ & * & & & \\
\hline
\end{tabular}




\begin{tabular}{|c|c|c|c|c|c|c|c|c|c|c|}
\hline 10 & Technical specification & $*$ & $*$ & & & & & & & * \\
\hline 11 & Technology transfer & $*$ & $*$ & * & * & & & & & * \\
\hline 12 & Reduced lifecycle cost & $*$ & $*$ & & & & $*$ & & & * \\
\hline 13 & Overall risk containment & $*$ & & & * & & & $*$ & & \\
\hline 14 & Reduced occurrence of disputes & $*$ & $*$ & & & * & & $*$ & $*$ & \\
\hline 15 & Price of housing in relation to income & * & $*$ & & * & * & & & $*$ & * \\
\hline 16 & Rental costs in relation to income & $*$ & $*$ & & & & & & $*$ & * \\
\hline 17 & Cost of transportation in relation to income/ transportation time & * & $*$ & * & & & & * & * & * \\
\hline 18 & $\begin{array}{l}\text { Waiting time of applicants before being allocated a housing unit/ Rate of } \\
\text { delivery of individual house-units }\end{array}$ & $*$ & $*$ & & * & & & & & \\
\hline 19 & Upgradation of living standards & $*$ & & * & & & & * & $*$ & * \\
\hline 20 & Take-up rate of facility & * & * & & & & & * & & * \\
\hline 21 & Maintability & & $*$ & $*$ & & & & $*$ & & $*$ \\
\hline 22 & Aesthetically pleasing & & $*$ & & & $*$ & & $*$ & $*$ & $*$ \\
\hline 23 & Material performance & & & $*$ & & & & $*$ & & \\
\hline 24 & Goal-achieving & & & & & $*$ & & & & \\
\hline 25 & Cater for Disables & & & & & & & $*$ & & \\
\hline
\end{tabular}

Table 1: Critical Success Criteria on Sustainable Housing Derived Through the Systematic Literature Review

(Adabre \& Chan, 2018), Hong Kong; b-(Chan \& Adabre,2019), Hong Kong- (Bakar, Razak, Abdullah, Awang, \& Perumal, 2010), Singapore; d- (Ahadzie, Proverbs, \& Olomolaiye, 2007), UK; e- (Mukhtar, Amirudin, \& Sofield, 2016), Nigeria; f- (Chan \& Chan,, 2004, Hong Kong; g- (Wail, Yusof, \& Ismail, 2012 ), Malaysia; h(Olanrewaju \& Tan, 2018), Malaysia; i- (Mulliner \& Maliene, 2011), UK; j- (Cox, Issa, \& Ahrens, 2003 ), USA; k- (Saidu \& Yeom, 2020), Nigeria.

\section{Analysis of Data and Interpretation of Results}

\subsection{CHARACTERISTICS OF THE SAMPLE}

\subsubsection{Analysis of the Profile of Professionals participated in KIIs}

The expert survey was pooled over 30 expert forms and 27 completed responses were received during the relevant period. Almost all have obtained a degree in the accepted university of a country with postgraduate education levels. Based on the profiles most of these experts are from architectural background and planning professionals as these criteria rely on the designing phase.

\begin{tabular}{|c|c|c|c|c|}
\hline $\begin{array}{l}\text { Professional } \\
\text { Background } \\
\end{array}$ & Architects & $\begin{array}{l}\text { Planning professionals (Town Planners, } \\
\text { Planning officers) }\end{array}$ & Engineers & Other \\
\hline Frequency (\%) & $42.9 \%$ & $46.6 \%$ & $7.2 \%$ & $3.6 \%$ \\
\hline
\end{tabular}

Table 2 : Distribution of Expert's Professional Backgrounds

\begin{tabular}{|l|l|l|l|l|l|l|}
\hline $\begin{array}{l}\text { Working } \\
\text { experience }\end{array}$ & $\begin{array}{l}\text { Less than 5 } \\
\text { yrs. }\end{array}$ & $\begin{array}{l}\text { More than 5 } \\
\text { yrs. }\end{array}$ & $\begin{array}{l}\text { Less than 10 } \\
\text { yrs. }\end{array}$ & $\begin{array}{l}\text { More than 10 } \\
\text { yrs. }\end{array}$ & $\begin{array}{l}\text { Less than 20 } \\
\text { yrs. }\end{array}$ & $\begin{array}{l}\text { More than 30 } \\
\text { yrs. }\end{array}$ \\
\hline Frequency \% & $14.3 \%$ & $17.9 \%$ & $14.3 \%$ & $32.1 \%$ & $10.7 \%$ & $7.1 \%$ \\
\hline
\end{tabular}

Table 3: Distribution of Expert's Working Experiences

As the low-income people are provided houses by the government with the intention of providing a house in affordable rates these government institutions are pooled with the experts who are involve in these traditions including Urban Development Authority, National Housing Development Authority, Urban Settlement Development Authority and Sewanatha.

\subsubsection{Analysis of the Profiles of Community participated in Questionnaire Survey.}

This research was done focusing three case study selections naming Sayurapura housing scheme, Henemulla housing scheme and Sobasiripura housing scheme covering the main implementation bodies of 
low-income housing projects on low-income people. Different definitions have been presented by the different institutions to define the low-income social class in the Sri Lankan Context.

Most low-income households are not "bankable" and cannot afford access to formal housing finance. The banks classify about $80 \%$ of the nation's earners as low income. Only $20 \%$ of all low-income earners have regular employment, potentially allowing them access to bank loans for finished housing. According to Department of Census and Statistics of Sri Lanka income classes have been divided as below. The monthly household income of the low-income household lies between Rs.14,843 - Rs. 22,423 and middle income 22,423- and middle-income household is Rs. 46,097. (Household Income and Expenditure Survey 2016). When provisioning of houses, UDA, NHDA and USDA has mainly concerned on the aspect of underserved settlements in which not owning a legal right to land ownership and upgrading the lives by providing facilities without concerning the income levels into much considerations. The concept of affordability has been considered in related to the ownership of the house.

When consider about the monthly income and expenses of these family's highest percentage of $49.4 \%$ lies between 25000-30000 income range. $21 \%$ lies on the income range of 10000-20000. $2.2 \%$ is in the income range of above 50000. In the expenditure aspects above 30000 expenses range is recorded as the highest with $32 \%$. Although there are classifications on the income ranges these families belong to middle income category including lower middle-income, middle income and upper middle income.

\subsection{DEFINING SUSTAINABLE HOUSING}

As per interviewed expert's perception "Sustainable housing is a type of housing with combination of green eco-friendly, energy efficient, affordable which balances the economic social and environmental equilibrium with community participation"

According to the literature backgrounds, "Sustainable housing is a type of housing endowed with green eco-friendly, energy efficient, affordability which balances the environmental economic social equilibrium"

In Both, literature and experts' perception, sustainable housing is interpreted as housing practice equilibrates environment, economic and social sustainability with eco-friendly green, energy efficient and affordable housing design. Experts highlighted that Sustainable housing should be a people centric with social capital to reorganize with community participation.

\subsection{CRITICAL SUCCESS CRITERIA OF SUSTAINABLE HOUSING}

\subsubsection{CSC of Sustainable Housing: a global perception based on literature}

Critical Success Criteria on Sustainable low-income housing referring to the design stage of houses were derived through literature with two contexts of Developed and developing countries.

\begin{tabular}{|c|c|c|c|c|c|c|c|c|}
\hline \multirow[b]{2}{*}{ CSC } & \multicolumn{6}{|c|}{ REFERENCES } & \multirow[b]{2}{*}{ Normalization } & \multirow[b]{2}{*}{ Ranking } \\
\hline & A & $\mathrm{b}$ & $\mathrm{c}$ & $\mathrm{d}$ & $\mathrm{e}$ & $\mathrm{f}$ & & \\
\hline $\begin{array}{l}\text { Efficiency of water and energy } \\
\text { use }\end{array}$ & 0.856 & 0.000 & 0.000 & 0.862 & 0.768 & 1.881 & 0.931 & 1 \\
\hline Material performance & 0.000 & 0.000 & 0.795 & 0.853 & 0.788 & 0.000 & 0.926 & 2 \\
\hline Cater for Disables & 0.000 & 0.000 & 0.000 & 0.840 & 0.000 & 0.000 & 0.926 & 2 \\
\hline Functionality of housing & 0.839 & 0.000 & 0.000 & 0.000 & 0.784 & 1.800 & 0.912 & 4 \\
\hline $\begin{array}{l}\text { User's satisfaction/ } \\
\text { End users Satisfaction }\end{array}$ & 0.812 & 0.815 & 0.640 & 0.000 & 0.784 & 0.000 & 0.890 & 5 \\
\hline Quality of project & 0.686 & 0.813 & 0.818 & 0.885 & 0.854 & 1.560 & 0.869 & 6 \\
\hline Schedule performance & 0.788 & 0.765 & 0.644 & 0.000 & 0.772 & 0.000 & 0.866 & 7 \\
\hline $\begin{array}{l}\text { Cost of transportation in } \\
\text { relation to income/ } \\
\text { transportation time }\end{array}$ & 0.631 & 0.000 & 0.000 & 0.907 & 0.823 & 2.028 & 0.861 & 8 \\
\hline Upgradation of living Standards & 0.653 & 0.800 & 0.844 & 0.000 & 0.784 & 0.000 & 0.859 & 9 \\
\hline Environmental performance & 0.530 & 0.909 & 0.842 & 0.791 & 0.788 & 2.336 & 0.858 & 10 \\
\hline $\begin{array}{l}\text { Price of housing in relation to } \\
\text { income }\end{array}$ & 0.649 & 0.772 & 0.868 & 0.000 & 0.752 & 1.930 & 0.845 & 11 \\
\hline
\end{tabular}




\begin{tabular}{|l|c|c|c|c|c|c|c|c|} 
Aesthetically pleasing & 0.649 & 0.000 & 0.000 & 0.826 & 0.784 & 2.048 & 0.844 & $\mathbf{1 2}$ \\
\hline Safety Health Performance & 0.610 & 0.760 & 0.721 & 0.616 & 0.854 & 1.818 & 0.793 & $\mathbf{1 3}$ \\
\hline Technical specification & 0.658 & 0.000 & 0.000 & 0.748 & 0.000 & 0.000 & 0.787 & $\mathbf{1 4}$ \\
\hline Technology transfer & 0.600 & 0.767 & 0.000 & 0.000 & 0.000 & 0.000 & 0.749 & $\mathbf{1 5}$ \\
\hline $\begin{array}{l}\text { Rental costs in relation to } \\
\text { income }\end{array}$ & 0.506 & 0.000 & 0.791 & 0.000 & 0.752 & 1.672 & 0.738 & $\mathbf{1 6}$ \\
\hline Maintability & 0.641 & 0.000 & 0.000 & 0.419 & 0.000 & 0.000 & 0.653 & $\mathbf{1 7}$ \\
\hline
\end{tabular}

Table 4: Ranking of Literature based Criteria

\subsubsection{CSC of Sustainable Housing: a local perception based on expert opinion}

The criteria derived through the literature were reexamined through experts' view. Users' satisfactions ranked with highest importance. Upgradation of Living standards (Sustainable developments) ranked second place. Quality of housing ranked in third place. As the quality of housing was a topmost criterion considered during the beginning of the CSC concept these experts also prove the importance even today. Efficiency of water and Energy use ranked with fourth place. Environmental performance and Maintainability both ranked with fifth importance.

Functionality of housing and cater for disables were ranked in sixth place. Price or rents of housing in relation to income and Material Performances are ranked in seventh position. The eight and nineth places were occupied by the Technical Specification and Safety / Health Performance making construction specifications are in middle importance.

The least important criteria were identified as Technology Transfer, Aesthetically Pleasing, Schedule performance and Cost of transportation in relation to income/transportation time. Other than the criteria found on literature reviews, two criteria were highlighted through the expert's KII. They are,

1. Public Consultation and Community participation

2. Existence of a regulatory framework in designing

According to the expert's idea Public Consultation and Community Participation to be done in the design phase related to participatory planning so as to get the ideas of the community for the success of the project. They pointed out that the existence of a regulatory framework in design process is important. As these follows a sustainable policy sustainable regulatory framework to be followed in order to assure the sustainability.

\subsubsection{CSC of Sustainable Housing: a local perception based on community views}

The combination of literature criteria and experts' survey were presented to the residents of three housing schemes to identify the importance of these criteria. According to the community perception following analysis shows the rankings. Cater for disables lies among the lowest ranks with the assumption of nonavailability of disables in these houses caused less attention. Existence of regulatory framework in designing process which derived from the experts is ranked with low importance by community. It can be concluded that as community is not much aware on the frameworks this answer has come.

\begin{tabular}{|c|c|c|c|c|c|c|c|c|c|c|c|}
\hline CODE & CRITERIA & $\begin{array}{c}\text { NOT } \\
\text { IMPORTANT } \\
\mathbf{1}\end{array}$ & $\begin{array}{c}\text { LESS } \\
\text { IMPORTANT } \\
2\end{array}$ & $\begin{array}{c}\text { NEUTRAL } \\
3\end{array}$ & \begin{tabular}{|c} 
IMPORTANT \\
$\mathbf{4}$
\end{tabular} & $\begin{array}{c}\text { VERY } \\
\text { IMPORTANT } \\
\mathbf{5}\end{array}$ & TOTAL & No. & $\mathbf{A}^{*} \mathbf{N}$ & RII & RANKING \\
\hline CSC 01 & \begin{tabular}{|l} 
Quality of \\
Housing
\end{tabular} & 0 & 6 & 12 & 112 & 725 & 855 & 180 & 900 & 0.9500 & 1 \\
\hline CSC 03 & $\begin{array}{l}\text { Health Safety } \\
\text { Performance }\end{array}$ & 1 & 4 & 15 & 140 & 685 & 845 & 180 & 900 & 0.9389 & 2 \\
\hline $\operatorname{CSC} 17$ & \begin{tabular}{|l|} 
Public \\
consultation and \\
community \\
participation
\end{tabular} & 1 & 4 & 30 & 100 & 710 & 845 & 180 & 900 & 0.9389 & 2 \\
\hline $\operatorname{CSC} 05$ & $\begin{array}{l}\text { User's } \\
\text { satisfaction/ End } \\
\text { users } \\
\text { Satisfaction }\end{array}$ & 1 & 2 & 33 & 124 & 680 & 840 & 180 & 900 & 0.9333 & 4 \\
\hline
\end{tabular}




\begin{tabular}{|c|c|c|c|c|c|c|c|c|c|c|c|}
\hline $\operatorname{CSC} 14$ & $\begin{array}{l}\text { Cost of } \\
\text { transportation in } \\
\text { relation to } \\
\text { income/ } \\
\text { transportation } \\
\text { time }\end{array}$ & 1 & 4 & 51 & 128 & 640 & 824 & 180 & 900 & 0.9156 & 5 \\
\hline CSC 04 & $\begin{array}{l}\text { Environmental } \\
\text { performance }\end{array}$ & 0 & 2 & 30 & 220 & 570 & 822 & 180 & 900 & 0.9133 & 6 \\
\hline $\operatorname{CSC} 12$ & $\begin{array}{l}\text { Upgradation of } \\
\text { living standards }\end{array}$ & 2 & 4 & 24 & 244 & 535 & 809 & 180 & 900 & 0.8989 & 7 \\
\hline $\operatorname{CSC} 09$ & $\begin{array}{l}\text { Technology } \\
\text { transfer }\end{array}$ & 1 & 10 & 72 & 156 & 555 & 794 & 180 & 900 & 0.8822 & 8 \\
\hline CSC 07 & $\begin{array}{l}\text { Functionality of } \\
\text { housing }\end{array}$ & 1 & 6 & 57 & 228 & 500 & 792 & 180 & 900 & 0.8800 & 9 \\
\hline CSC 08 & $\begin{array}{l}\text { Technical } \\
\text { specification }\end{array}$ & 1 & 12 & 78 & 136 & 565 & 792 & 180 & 900 & 0.8800 & 9 \\
\hline $\operatorname{CSC} 10$ & $\begin{array}{l}\text { Aesthetically } \\
\text { pleasing }\end{array}$ & 0 & 4 & 78 & 220 & 485 & 787 & 180 & 900 & 0.8744 & 11 \\
\hline $\operatorname{CSC} 13$ & $\begin{array}{l}\text { Housing Price/ } \\
\text { Rents as a } \\
\text { fraction of } \\
\text { income }\end{array}$ & 3 & 12 & 66 & 160 & 545 & 786 & 180 & 900 & 0.8733 & 12 \\
\hline $\operatorname{CSC} 11$ & Maintainability & 1 & 4 & 69 & 236 & 475 & 785 & 180 & 900 & 0.8722 & 13 \\
\hline $\operatorname{CSC} 16$ & $\begin{array}{l}\text { Material } \\
\text { Performances }\end{array}$ & 1 & 10 & 63 & 244 & 460 & 778 & 180 & 900 & 0.8644 & 14 \\
\hline CSC 06 & $\begin{array}{l}\text { Efficiency of } \\
\text { Water and } \\
\text { Energy use }\end{array}$ & 0 & 4 & 75 & 284 & 410 & 773 & 180 & 900 & 0.8589 & 15 \\
\hline CSC 02 & $\begin{array}{l}\text { Schedule } \\
\text { performance }\end{array}$ & 0 & 8 & 42 & 412 & 295 & 757 & 180 & 900 & 0.8411 & 16 \\
\hline $\operatorname{CSC} 18$ & $\begin{array}{l}\text { Existence of a } \\
\text { systematic } \\
\text { regulatory } \\
\text { framework }\end{array}$ & 1 & 22 & 54 & 284 & 395 & 756 & 180 & 900 & 0.8400 & 17 \\
\hline $\operatorname{CSC} 15$ & $\begin{array}{l}\text { Cater For } \\
\text { disables }\end{array}$ & 7 & 34 & 66 & 216 & 400 & 723 & 180 & 900 & 0.8033 & 18 \\
\hline
\end{tabular}

Table 5: Ranking of CSC based on Community Views

\subsubsection{CSC of Sustainable Housing: A Comparison of Literature, Expert's and Community Perceptions}

This research has followed up analysis based on systematic literature review, professional experts survey and community perception questionnaire on selected case study areas to identify the importance of CSC on sustainable low-income housing in design stage. As the findings are different from each other perception a comparison is done to identify how these criteria are different.

When comparing the literature vs expert's opinions, Literature has ranked Efficiency use of water and energy in highest importance while experts have given fourth ranking causing a gap of 75\%. Then the experts have ranked user's satisfaction in top rank while literature in fifth place followed with a gap of $80 \%$. Upgradation of living standards and material performances have occupied a gap of $77.77 \%$ showing differences in rankings. Cater for disables too created a gap of $71.42 \%$ with the literature ranking of two and expert ranking of seven. Safety health performances and aesthetically pleasing have recorded with lowest gaps. New criteria were derived from the expert's view which were not mentioned in the literature review. Public consultation and community participation in the designing process and Existence of a regulatory framework in designing are newly derived. According to the professional's public consultation is highly important not only for the success but also satisfaction of the livelihoods.

When comparing the expert's opinion vs community perceptions experts have given highest importance to User's satisfaction while community ranked in fourth place creating a gap of $73.33 \%$. Upgradation of living standards criteria has been ranked in second place by experts while seventh rank in community following a gap of $71.42 \%$. Safety Health performances is ranked in second place by community while twelve places by experts. The most highlighted fact is that Public Consultation has given the second priority by the community. The community has ranked cost of transportation in relation to income in fifth place due to their experiences. During the survey community explained how the transportation facilities have been linked with their living conditions and it showed a significant value. A significant ranking has 
been given to Quality of housing by the community. Their responses emphasize that the quality of housing is a needy criterion for successful living.

When comparing the CSC of literature vs community perceptions, a significant difference has been given by Community and literature in the criteria of Quality of Housing, Safety Health Performances, Efficiency use of water and energy, Material Performance and Cater for disables. Community has ranked Quality of housing in first place while literature ranked sixth place. Safety and health performances is ranked in second place by community while thirteen places by literature. Efficiency Use of Water and energy is ranked in first place in literature while fifteenth place in literature. Literature has not established the Public Consultation and Community participation and Existence of a regulatory framework in designing as CSC. But experts established these criteria in this study as participatory planning is an important part in the designing process. When consider about the CSC ranking of the public, public consultation and Community participation in designing process ranked highest and most of the respondents revealed that community should be involved with this design stage without compromising into professionals. According to the given responses' public highlighted that the importance and need of community participation in designing stage to make these projects more sustainable and success.

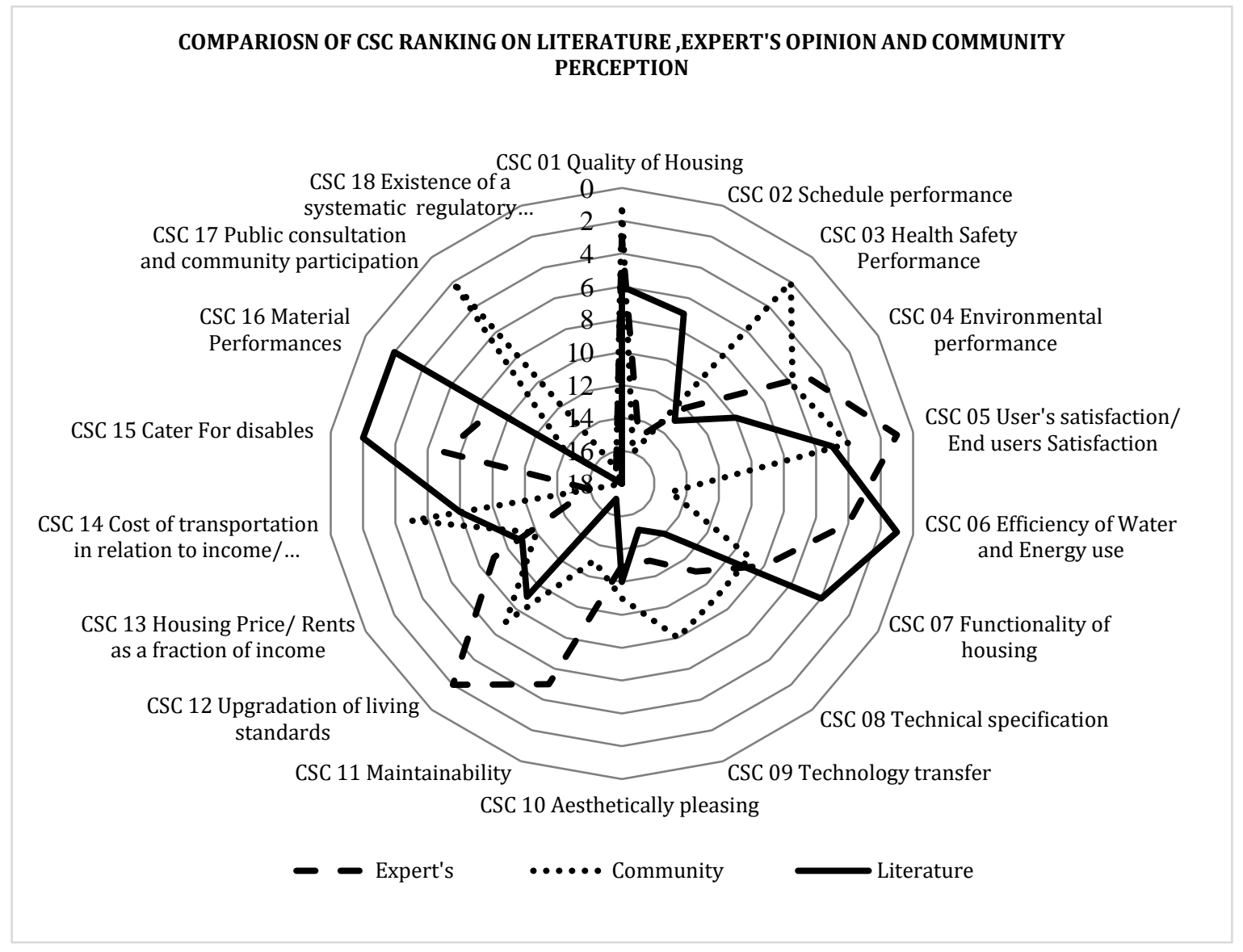

Figure 03: Comparison of CSC Ranking of Literature, Expert and Community.

\section{Conclusion and Recommendations}

Sustainable housing projects for low-income settlers are rapidly implementing in Sri Lanka and it has become a key need for the Urban Community. But the meaning of the success of a project changes from project to project and overtime. Identification of a success of a sustainable project is a complex task. But there are very limited studies on the identification of CSC on sustainable low-income housings in design stage. In such context this study attempted to identify the CSC on Sustainable low-income housing in design stage in Sri Lanka. Systematic literature review was done based on literature. Then the literature derived CSC were presented to professionals and residents on selected housing schemes to identify the importance of these criteria and RII was used to rank them with importance in data analysis. The objectives of this study were achieved through the identification and validation of the CSC and ranking them with the importance. 
These criteria including Quality of Housing, Schedule performance, Safety Health Performance, Environmental performance, User's satisfaction, Efficiency use of water and energy, Functionality of Housing ,Technical Specification, Technology Transfer, Aesthetically Pleasing , Maintainability, Upgradation of Living standards, Housing Price / Rent as a fraction of income, Transportation Cost with relate to income, Cater for Disables and Material Performances were derived through the literature as CSC in designing stage and reestablished in relate to the Sri Lankan context. The highest importance has been ranked with Efficiency use of water and energy, Users Satisfaction and Quality of Housing while least importance is ranked with Maintainability, Public Consultation and community participation and cater for Disables and by Literature, Experts and Community respectively. As this study concern with the design stage the cost performance was not significant with the Sri Lankan context. The criteria of Public Consultation and Community participation and Existence of a regulatory framework in designing were highlighted by the experts in expert survey.

Then Public Consultation and Community participation in design stage which was emphasized by the experts was highly demarcated by the public in public survey The re-established knowledge on CSC is applicable to Sri Lankan context and it is recommended to use them in planning practices in future developments by the planning professionals. It is recommended to identify the success criteria of each and every stage of a project cycle without framing into one stage. So that a comprehensive mathematical based index can be developed for the identified criteria of the different stages to measure the success. As each and every aspect endowed with good and bad sides there are some limitations of this study. One of the key limitations of this study is the lack of time to conduct the research and the practical difficulties to engage in the surveys with the prevailing pandemic situation of the country. Besides this study focused on a relatively small sample so that future research to be done with large number of 42 responses. As the low-income housing projects are concentrated among the government institutions lack of experts in the selected stream was a main limitation. Inherent subjectivity of individual value judgement might have constrained the generalizability of study. Future research works are recommended on large sample size extending the representativeness of the sample.

This research will support to create an overall sustainable development with the participation of low-income community concentrating into the rich community.

\section{References:}

Adabre, M. A. \& Chan, A. (2018). The ends required to justify the means for sustainable affordable housing : A review on Critical Success Criteria.

Ahadzie. D, Proverbs, D., \& Olomolaiye, P. (2007). CSC for mass house building projects in developing countries . International Journal of Project Management 26 (2008) , pp 675-687.

Athapaththu, K., \& Karunasena, G. (2018 ). Framework for sustainable construction practices in Sri Lanka . Built Environment Project and Asset Management Vol. 8 No. 1, pp.51-63 .

Bakar, A., Razak, A., Abdullah, S., Awang, A., \& Perumal, W. (2010). Critical Success Factors for Sustainable Houisng : a framework from the project management view. Asian Journal of Management Research 66.

Chan, A., \& Adabre, M. (2019). Bridging the gap between sustainable housing and affordable housing: The required critical successs criteria (CSC) . Building and Environment Vol 151, pp 112-125.

Chan, A., \& Chan, A. (2004). Key performance indicators for measuring construction success . Benchmarking: An International Journal , PP 203-221.

Chan, A., Scott, D., \& Lam, E. (2002). Framework of success criteria for design/build projects . Journal Of Management in Engineering 18(3), pp.120-128.

Chua, D., Kog, Y., \& Loh, P. (1999). Critical success factors for different project objectives, . J. Construct. Eng. Manag. 125 (3) , pp 142- 150 .

Cox, R., Issa, R., \& Ahrens, D. (2003 ). Management's Perception of Key Performance Indicators for Construction. JOURNAL OF CONSTRUCTION ENGINEERING AND MANAGEMENT @ ASCE / MARCH/APRIL 2003, pp 142-151.

Gan, X., Zuo, J., Wu, P., Wang, J., Chang, R., \& Wen, T. (2017). How affordable housing becomes more sustainable? A stakeholder study. Journal of Cleaner Production 162 , pp.427-437.

Godfaurd, J., Clements-Croome, D., \& Jeronimidis, G. (2005). Sustainable building solutions: a review of lessons from the natural world. Sustainable building solutions: a review of lessons from the natural world.Buiding Environment.40 (3), pp.319-328.

Hatush, Z., \& Skitmore, M. (1997). Criteria for Constractor Selection . Construction Managmenet and Economics , pp.1938.

John, G., \& Jeronimidis.G. (2005). Sustainable building solutions: a review of lessons from the natural world. Building and Environment. 40(3): 317-326. 
Kylili, A., Fokaides, P. A., \& \& Jimenez, P. A. (2016). Key performance indicators (KPIs) approach in buildings renovation for the sustainability of the built environment. A review .Renewable and Sustainable Energy Reviews, 56, pp. 906-915.

Lim, C., \& Mohamed, M. (1999). Criteria of Project Success: An Exploratory ReExamination. International Journal of Project Management 17:, pp.243-248.

Mukhtar, M., Amirudin, R., \& Sofield, T. (2016). Critical success factors for public housing projects in developing countries :a case study of Negeria .

Mulliner, E., \& Maliene, V. (2011). CRITERIA FOR SUSTAINABLE HOUSING AFFORDABILITY.

O'Brochta, M. (2002). Project success-what are the criteria and whose opinion counts. Project Management Institute Annual Seminars \& Symposium,. San Antonio, TX. Newtown Square, : Project Management Institute.

Olanrewaju, A., \& Tan, S. (2018). An exploration into design criteria for affordable houisng in Malaysia .

Pullen, S., Arman, M., Zillante, G., Zuo, J., \& Chileshe, N. a. (2010). Developing an Assessment Framework for Affordable and Sustainable Housing. Australasian Journal of Construction Economies and Building,10(1/2), pp.48-64.

Saidu, A., \& Yeom, C. (2020). Success Criteria Evaluation for a Sustainable and Affordable Housing Model: A Case for Improving Household Welfare in Nigeria Cities. Sustainability.

Srimathi, S., Dinesh, S., \& Sethuraman, R. (2017). A Review On Critical Success Factors In Construction Project. International Journal of Scientific Reserch in Science,Engineering and Technology 3 , pp 478-481.

Wail, S., Yusof, A., \& Ismail, S. (2012 ). Exploring SuccessCriteria from the Developers Perspective in Malaysia . International Journal of Engineering Business Management.

Xiaosen, H., Ann, T., Amos, D., \& Zezhou, W. (2019). Critical factors in site planning and design of green buildings:A case of China. J.Clean Production, pp.685-694.

Yang, J., \& Yang, Z. (2015). "Critical factors affecting the implementation of sustainable housing in Australia. Journal of Houisng and the Built Environment, Vol.30 No.2,, pp.275-292. 